\title{
Hvordan gjøre en \\ vellykket datainnsamling
}

\section{Man kan gå i diverse feller når man samler inn data ved hjelp av fokusgruppeintervju.}

Terje Årsvoll Olsen

Førstelektor

Desentralisert sjukepleiarutdanning, Høgskulen på Vestlandet

Fokusgrupper Fokusgruppeintervju

Sykepleien Forskning 201914 (57456) (e-57456)

DOI: 10.4220/Sykepleienf.2019.57456

Utgangspunktet for denne artikkelen er veien frem mot å besvare følgende forskningsspørsmål: «Hvorfor vil om lag 2 prosent av siste års sykepleiestuderende velge sykehjem som arbeidsplass?» Tanken er å få belyst de prosessene som man skal lykkes med for å få frem data av god kvalitet gjennom bruk av fokusgrupper.

Interessen for selve studien ble vekket i september 2007. Da fortalte avisen Stud-Vest i Bergen at «ingen» vil jobbe i sykehjem. Det kom frem at sykepleierstudentene opplevde dårlig oppfølging under praksisopphold i sykehjem, og konsekvensen var at bare 2,2 prosent фnsket å jobbe med eldreomsorg. (I 2016 var det tilsvarende tallet 6,4 prosent ifølge NRK Rogaland.)

Jeg ønsket å fokusere på de positive sidene. Det skulle imidlertid vise seg vanskelig. Og det er her denne artikkelen tar form. Artikkelen setter søkelys på det som gikk galt i denne prosessen, i håp om at flere kan unngå å gå i de samme fellene, og for å vise hvorfor det er nyttig å gjennomføre en pilotunders $\varnothing$ kelse først. 
Datainnsamlingsmetode og deltakere til studien ble valgt med utgangspunkt i et ønske om å kartlegge så mange oppfatninger som mulig. Malterud (1) beskriver datainnsamling ved hjelp av fokusgrupper. Denne tilnærmingsformen er godt egnet hvis man leter etter synspunkter i et miljø der mange mennesker samhandler (1). Sykepleierstudenters kliniske praksisstudier i sykehjem innebærer samhandling med mange personer med forskjellige oppgaver.

Metoden foretrekkes fremfor individuelle intervjuer for å oppnå bredde og variasjon i oppfatningene. Jeg vil her drøfte noen utfordringer knyttet til utvalget og til gjennomføringen av intervjuene.

\section{Hva som kan gå galt}

Jeg valgte først å sende ut et spørreskjema til sykepleierstudenter som nettopp hadde vært i praksisstudier i et sykehjem. Disse var førsteårsstudenter på ordinært program og tredjeårsstudenter på desentralisert program ved Høgskolen i Bergen. Dette hadde tre formål:

1. Først å finne så mange informanter som mulig ved Høgskolen i Bergen. Jeg visste at bare om lag 2,2-4,2 prosent av sykepleierstudentene $\varnothing$ nsket jobb i sykehjem, og at det ikke var mange som hadde positive ting å melde. Dermed var det ikke mange igjen som kunne si seg villig til å delta i fokusgrupper.

2. Så ønsket jeg å kartlegge områder informanter som hadde tenkt å jobbe i sykehjem, var opptatt av.

3. Dernest $\varnothing$ nsket jeg å skape interesse for unders $\varnothing$ kelsen og invitere dem som var positive til det å jobbe i sykehjem, til å delta på fokusgruppeintervju.

Intensjonen med datamaterialet fra spørreskjemaene var ikke å bruke det i selve unders $\varnothing$ kelsen, men å få hjelp til å lage en samtaleguide. Jeg ønsket å få fatt på hva som hadde vært medvirkende faktorer til at studentene kunne tenke seg å begynne å jobbe i sykehjem, slik at jeg kunne gå i dybden på dette i gruppeintervjuene.

Allerede her dukket det opp store utfordringer. Tretten av de 55 som svarte, $\varnothing$ nsket å jobbe i sykehjem. Totalt var det 220 første- og tredjeårsstudenter ved Høgskolen i Bergen som fikk spørreskjemaet. 
For å utvide muligheten til å få et tilstrekkelig antall informanter som sto på trappene til sykepleieryrket, inviterte jeg avgangsstudenter ved alle de tre lærestedene Høgskolen i Bergen (HiB), Universitetet i Stavanger (UiS) og Høgskolen i Nesna (HiNesna) til gruppeintervju. Til sammen 15 informanter av 530 mulige $\varnothing$ nsket å delta, fordelt slik: én fra Betanien, ingen fra Haraldsplass, seks fra $\mathrm{HiB}$, tre fra UiS og fem fra HiNesna.

Mye gikk galt. Tidspunktet for gjennomføringen av gruppeintervjuene falt sammen med en ellers travel periode $i$ studiet. Studentene holdt på med siste praksisperiode eller avsluttende eksamen. Å delta i en slik samtale ville for mange bety at de ikke nådde toget eller fergen hjem den dagen.

Ikke alle fikk spørreskjemaet først, og jeg presenterte ikke selv ansikt til ansikt hensikten med studiet, men la en invitasjon ut på Itslearning og ba lærere oppmuntre folk til å stille. Invitasjonen gikk gjennom en tredjeperson. Katastrofen var et faktum.

\section{Intervjuet}

I alt forskningsarbeid avgjør formålet med forskningen hvilken metode som er hensiktsmessig (2). Man kan velge individuelle intervjuer, gruppeintervjuer eller fokusgrupper. Jeg valgte det jeg kalte fokusgruppeintervju, altså en krysning av fokusgruppe og gruppeintervju. Min intensjon i det videre er å klargjøre hva som er hva.

Et kvalitativt forskningsintervju er hensiktsmessig blant annet når man ønsker å kartlegge opplevelser, motiver og vurderinger hos mennesker. I dette tilfellet var jeg interessert i de vurderingene og motivene som lå bak at noen ønsker å jobbe i sykehjem.

Christensen og medarbeidere (2) påpeker at kvalitativ forskningsmetode innbefatter både intervju, observasjoner og feltstudier samt analyse av allerede eksisterende tekstmateriale. Det meste som er skrevet om arbeid i sykehjem, er av negativ karakter.

I et forskningsintervju stiller intervjueren spørsmål til informantene om forhold som berører det forskeren $\varnothing$ nsker å finne svar på. Når jeg skal finne gode spørsmål, må jeg tenke over hvilke kjerneområder det er viktig å berøre. I en sammenheng der det er mest oppmerksomhet rundt negative forhold, er det viktig å tenke over hvordan man skal bevare en positiv vinkling i samtalen. 
Som Christensen og medarbeidere (2) påpeker, kan slike intervjuer befinne seg på en skala fra strukturerte, standardiserte, kvantitative intervjuer der spørsmålene er gitt og svarene hakes av i faste svarkategorier, til helt åpne intervjuer hvor informanten blir bedt om å fortelle om sitt forhold til temaområdet det forskes på.

Jeg forestilte meg at noen forhold påvirket valget om å jobbe i sykehjem mer enn andre. Jeg ønsket å finne ut om disse forholdene hadde betydning for valget av arbeidsplass etter endt utdanning. Jeg valgte derfor det Kvale kaller semistrukturert intervju (3). Det betyr at det var noen fastlagte emneområder jeg ønsket å spørre om.

Utfordringen når jeg skal lage en slik intervjuguide, er å være både lukket nok og åpen nok samtidig: lukket nok til å sikre at alle samtalene kommer inn på de samme temaområdene, slik at områdene kan bli belyst med best mulige data, og åpne nok til at det ikke settes stengsler for andre ting informantene måtte $\varnothing$ nske å sette søkelys på.

\section{Gruppeintervjuer eller individuelle intervjuer?}

Stewart og medarbeidere påpeker at fokusgrupper, uansett fagområde, har noen hovedelementer som bør ivaretas (4). For det første det Merton kaller «focused». Det vil si at deltakerne skal ha erfaringer fra en «particular concrete situation» (4, s. 9) som danner fokus i intervjuet. Hvis det er for mange fokus, beskriver Merton det som en «out-offocus»-gruppe.

For det andre må man være bevisst gruppedynamikk og interaksjon mellom deltakerne. Tre nøkkelelementer virker direkte inn på om det virkelig kommer noe mer ut av å intervjue i grupper enn individuelt. Disse elementene er gruppesammensetningen, den mellommenneskelige innflytelsen og omgivelsene (4).

For det tredje skal fokusgrupper gå i dybden. Hvis forskeren har for mange spørsmål, blir resultatet snarere en «withingroup»-unders $\varnothing$ kelse - det vil si et gruppeintervju og ikke en interaktiv gruppeprosess (4).

Endelig påpeker Stewart, Shamdasani og Rook (4) at kvalitativ forskning er «kontaktsport», og at for å lykkes må empati, åpenhet, aktiv lytting og andre ulike samhandlingsforhold være på plass. 
Jeg må være bevisst på at det ikke er en samtale jeg har. Det som skiller det kvalitative forskningsintervjuet fra andre samtaler, er den metodiske bevisstheten rundt spørreformen. Den dynamiske bevissthet om interaksjonen mellom meg som intervjuer og den som blir intervjuet. Det er en kritisk bevissthet rundt det som sies og mine tolkninger av det som blir sagt.

Individuelle intervjuer vil ha en utdypende og forklarende tilnærming til den enkelte personen som deltar, og er mer hensiktsmessig om jeg trenger detaljert og nøye informasjon om individuelle holdninger og tanker omkring et fenomen.

Jeg kan lettere følge en tidslinje, for eksempel følge opp endringer i innstillinger over tid, om utdanningen har spilt noen rolle for standpunktet, eller om andre forhold fra livet før utdanningen ligger bak. Jeg kan gå bak sosialt akseptable synspunkter og bevege meg inn på sensitive eller intime emner som man kanskje ikke ville snakke åpent om dersom medstudenter var til stede.

\section{$\equiv$ «Fokusgrupper er ikke det samme som gruppeintervju.»}

I fokusgrupper får jeg mer bredde gjennom den påvirkningen informantene har på hverandre. Det betyr at jeg kan få et bredere spekter av innstillinger og meninger fordi gruppen minner hverandre på ulike synspunkter. Det kan bidra til en større kreativitet i tilnærmingen.

Fokusgrupper er ikke det samme som gruppeintervju. Gruppeintervju har en høy grad av interaksjon mellom intervjupersoner og intervjuer. Intervjueren setter søkelyset og bærer samtalen videre, i mitt tilfelle ved hjelp av en semistrukturert intervjuguide. Fokusgrupper legger større vekt på samhandlingen mellom deltakerne. Det er de som i samtalens løp definerer samtalens innhold.

Fokusgrupper kombinerer gruppeinteraksjon og emnefokus og er på sett og vis en blanding av gruppeintervju og gruppearbeid (5). Moderatoren skal holde oppmerksomheten i samtalen og oppmuntre til debatt mellom deltakerne (6). En fokusgruppe skal bære preg av å være en samtale mellom deltakerne, og ikke et intervju. 
$\AA$ bruke fokusgrupper skal være en forskningsmetode hvor data blir produsert ved gruppeinteraksjon omkring et emne som forskeren har bestemt. I mitt tilfelle erfarte jeg at min rolle som høyskolelektor hadde en meget sterk innvirkning på samtalens forløp. Informantene henvendte seg i meget stor grad til undertegnede i samtalen. De snakket til meg selv om de kommenterte ting en annen informant hadde sagt.

I denne situasjonen burde jeg hatt med en assistent som gjorde notater og bidro til å holde fokus. Uten denne medspilleren opplever jeg at jeg ikke har hatt fokusgrupper omkring positive faktorer for valg av sykehjem som arbeidsplass, men i stedet hatt gruppeintervju.

\section{Intervjuundersøkelsens kvalitet}

Kvaliteten på et intervju avhenger av mange faktorer. Det er viktig å være godt forberedt. Valg av sted kan spille en avgjørende rolle. Av praktiske grunner valgte jeg å samle mine informanter på deres respektive studiesteder.

Det er selvsagt en vurderingssak hva som er det optimale stedet for en samtale rundt yrkesvalg. Poenget er at informantene skal føle seg trygge og ikke ha press på seg til å svare i noen spesiell retning.

Det var viktig å sørge for at rommet var tilstrekkelig skjermet, med ro til å gjennomføre samtalen uten forstyrrelser. I alle intervjusituasjonene lyktes vi med det.

Jeg gjennomførte tre gruppeintervjuer, et med seks deltakere og et med tre deltakere, som jeg har data fra, samt et med fem deltakere, som jeg ikke har data fra fordi teknikken sviktet. Alle gruppene var glade for at det ble fokusert på positive forhold ved det å jobbe i sykehjem. Alle hadde planer om å jobbe i sykehjem.

\section{$\equiv$ «Det er viktig å være godt forberedt.»}

Jeg valgte å bruke en $\mathrm{MP}_{3}$-spiller for å ta opp samtalene. Dette kan virke forstyrrende på en samtale fordi noen kan bli redde for å si hva de egentlig mener om ting som kan slå tilbake på dem. Derfor er det viktig å redegjøre for hvordan man håndterer materialet i etterkant med tanke på oppbevaring og utskrift. I mitt tilfelle informerte jeg om anonymisering av svarene og at materialet ville bli slettet når unders $\varnothing$ kelsen var gjennomført og materialet bearbeidet. 
Jeg valgte å informere om at opptakeren hadde en god mikrofon, slik at deltakerne slapp å strekke seg mot mikrofonen. Spilleren ville fange opp det som ble sagt.

Christensen og medarbeidere (2) påpeker at det er viktig å ha en «myk» innledning, der man forteller om formålet med unders $\varnothing$ kelsen og hvilke temaer man $\varnothing$ nsker å ta opp. Jeg understrekte at jeg hadde en liten guide for hva jeg ønsket å diskutere, men at det var fritt opp til dem å ta opp temaer de selv syntes var viktige. Den innledende småpraten er viktig for å skape en avslappet stemning og ta oppmerksomheten bort fra MP3-opptakeren.

For meg ble det viktig å skape en forståelse for at jeg ville fors $\varnothing$ ke å avlede negativ oppmerksomhet som dukket opp i løpet av samtalen. Dette var nødvendig siden jeg vet at det er mye negativitet rundt forhold i sykehjem, og siden min unders $\varnothing$ kelse skulle dreie seg om positive faktorer.

I forbindelse med et forskningsprosjekt er dette en viktig avklaring med tanke på om jeg skal ha enkeltintervju, fokusgrupper eller gruppeintervju, siden forskerens rolle er forskjellig i de ulike tilnærmingene.

\section{Fra intervjuguide til gruppeintervju}

Basert på svarene i nevnte spørreskjema var jeg interessert i å få en oversikt over hva folk opplevde som positivt ved å jobbe i sykehjem. Ideen med utvalget var at deltakerne nylig hadde erfart sykehjemmet og de faktorene som kunne påvirke $\emptyset$ nsket om å jobbe i sykehjem.

Jeg ønsket på basis av svarene å justere min oppfatning av hva det var viktig å rette oppmerksomheten mot. Kvale skiller mellom en tematisk og en dynamisk dimensjon på intervjuspørsmålene (3). Intervjuguiden bør både ta utgangspunkt i den problemstillingen som er satt, og være slik at jeg kan fange opp det gruppen ønsker å snakke om. $\AA$ lage et spørreskjema på forhånd kan hjelpe meg til å være forberedt på de innspillene som kommer i samtalen.

Når man skal gjennomføre et kvalitativt forskningsintervju, er det viktig å gjøre noen vurderinger av hvor lang tid ting skal ta. Flere forhold påvirker. Tidsrammen bør ikke være for lang. Det er vanlig å anbefale at det ikke bør gå særlig over to timer. Dette er smertegrensen for når konsentrasjonen glipper. 
Poenget er å få informantene til å fortelle, drøfte og reflektere naturlig og fritt, ved å vise støtte både nonverbalt og verbalt, gjennom håndbevegelser, nikk, smil, relevante ansiktsuttrykk og så videre. Videre er det viktig å etterspørre og få bekreftet eller avkreftet egne oppfatninger av det som blir sagt underveis. Det betyr å kommentere og spørre. Slike tilbakemeldinger vil også holde informanten innenfor det hovedtemaet som er valgt.

Utfordringen var å sikre at det ble snakket om positive forhold ved å jobbe i sykehjem - særlig fordi samtalen rundt sykehjem dessverre gjerne havner i det negative fokuset vi ofte finner, blant annet i pressen. Begrunnelsen for dette ligger i hensikten med forskningsprosjektet: Hvorfor $\varnothing$ nsker disse studentene å jobbe i sykehjem? Samtidig ligger det i den vitenskapelige tilnærmingen en åpenhet til informantene.

Jeg fors $\varnothing$ kte derfor likevel å gå åpent ut: «Hva er det som gjør at dere kan tenke dere å jobbe med gamle?» Deretter handler det om å lytte til svaret og prøve å komme bak ordene som blir sagt, uten å påvirke retningen det tar.

\section{三 «Jeg må være våken for om mine spørsmål treffer noe viktig.»}

Jeg bør lese mellom linjene og være oppmerksom på intonasjon og emosjonelt trykk. Det kan være selvmotsigelser og indre motsigelser i budskapet som det er viktig å sikre seg en forståelse av (7). Det kan handle om ambivalens eller tabubelagte områder jeg ikke er oppmerksom på, for eksempel kulturforskjeller mellom utdanninger. Slike ting er desto mer interessante for de dataene jeg vil få frem.

Jeg må være våken for om mine spørsmål treffer noe viktig, eller om de ikke blir forstått og informanten bare svarer noe ut fra høflighet. Kan jeg klare å sjekke troverdigheten gjennom å stille det samme spørsmålet fra ulike vinkler, kan det være nyttig. Jeg må være oppmerksom på tegn på unnvikelse og avvisning av bestemte problemstillinger. Da kan det være nyttig å omformulere et spørsmål og ta det opp igjen.

Det er viktig å gi svarerne ro til å snakke ut. Her var jeg ikke tilstrekkelig bevisst på om jeg hadde en fokusgruppe eller et gruppeintervju. Min «høyskolelektorrolle» fikk for stor plass, slik at jeg fikk gruppeintervju og ikke fokusgruppe. 
Jeg prøvde å ikke snakke for mye og ikke forklare for mye, men likevel gikk nesten alltid samtalen via meg. Jeg måtte stille oppfølgingsspørsmål for å få samtalen til å flyte - ikke bare når det var nødvendig for å belyse visse deler av emnet, eller når det ble snakk om det negative i stedet for det positive.

\section{Bruk av MP3 og flyt i samtalen}

Ideelt sett skal en båndopptaker frigjøre oppmerksomhet i intervjusituasjonen. Jeg kan være våkent opptatt av det som blir sagt, og spille inn mine oppfølgingsspørsmål i samtalen.

Jeg valgte derfor bort å gjøre notater underveis fordi jeg stolte fullt og helt på teknikken, og fordi jeg ikke ville la mine noteringer påvirke flyten i samtalen. Det var ikke lurt. Da jeg skulle skrive ut et av intervjuene, var $\mathrm{MP}_{3}$-opptaket tomt. Uten notater var det umulig å fremskaffe noe informasjon. Jeg var oppmuntrende til stede, men mistet alt.

Med tanke på å være oppmuntrende til stede kan det også tenkes at denne tilstedeværelsen var noe av det som gjorde at det ble gruppeintervju og ikke fokusgrupper. Det er naturlig å ta inn over seg at høyskolelektorstatusen har autoritet selv om du ikke direkte har vært lærer for alle informantene.

Imidlertid gir bruk av opptaksverkt $\varnothing y$ en mulighet til å observere nonverbal kommunikasjon, og på den måten kan man muligens bli i stand til å utfordre informantene. At man ikke trenger å bruke tankevirksomhet på å notere, kan gjøre det mulig å tenke ut neste trekk udistansert. Det kan gi rom for fleksibilitet på den måten at du er fullt og helt til stede og kan fange opp både ordene og det usagte.

\section{Til slutt}

Etter å ha lest ulik litteratur om fokusgrupper er jeg mer sikker på hva som er fokusgrupper, hva som skiller fokusgruppe fra gruppeintervju, og at det i prinsippet ikke er noe som heter fokusgruppeintervju $(5,8-10)$. Det jeg vet mer om, er at det er mange forhold som bør vurderes og kontrolleres om jeg skal lykkes med å få gode data av flere informanter samtidig og for å kunne kalle det fokusgrupper. 
Jeg har lært at gruppene bør være sammensatt av folk som har opplevd noe sammen, og som har et godt samspill der ingen dominerer, ei heller den som leder intervjuet eller samtalen. Fokusgrupper er billigere og gir, om de er gode, mer data enn et enkeltintervju fordi deltakerne genererer nye tanker hos hverandre hvis de spiller godt sammen.

Synergieffekten kan være god. Fokusgrupper gir forskeren anledning til å interagere med deltakerne og få avklart spørsmål der og da. Det gir en mulighet til å komme i dybden.

Det er ikke lett å trekke slutninger fra det relativt lille antallet deltakere til større befolkningsgrupper. Skjevheten ( bias) innen gruppen kan være sterk fordi deltakerne påvirkes av hverandre. Man kan ikke være sikker på om de virkelig står for det samme, eller om de er blitt påvirket av hverandre. Og endelig kan jeg som moderator påvirke resultatet bevisst eller ubevisst i en retning som er $\varnothing$ nskelig fra mitt ståsted gjennom å etterstrebe enighet i gruppen med mine innspill.

Jeg har lært at hvis jeg skal få gode og selvstendige svar på spørsmålet om hvorfor om lag 2,2-4,2 prosent av ferske sykepleiere ønsker å jobbe i sykehjem, bør jeg finne informanter som ikke har noe å vinne eller tape på å svare meg som forsker ærlig.

\section{Referanser}

1. Malterud K. Kvalitative forskningsmetoder for medisin og helsefag. 4. utg. Oslo: Universitetsforlaget; 2017.

2. Vallgårda S, Koch L, red. Forskningsmetoder i

folkesundhedsvidenskab. 4. utg. København: Munksgaard; 2011.

3. Kvale S, Brinkmann S. Det kvalitative forskningsintervju. 3 . utg. Oslo: Gyldendal Akademisk; 2015.

4. Stewart DW, Shamdasani PN, Rook DW. Focus groups. Theory and practice. 2. utg. Los Angeles: Sage; 2007.

5. Wibeck V. Fokusgrupper: om fokuserade gruppintervjuer som undersökningsmetod. 2. opplag. Lund: Studentlitteratur; 2010.

6. Lerdal A, Karlsson B. Bruk av fokusgruppeintervju. Sykepleien Forskning. 2008;3(3):172-5. 
7. Gadamer H-G. Sandhed og metode: grundtræk af en

filosofisk hermeneutik. 2. utg. Århus: Systime Academic; 2007.

8. Blåsternes E. Refleksjoner over bruk av fokusgrupper og utvikling av intervjuguide. (Upublisert eksamen.) Bergen:

Høgskolen i Bergen; 2008.

9. Halkier B. Fokusgrupper. Oslo: Gyldendal Akademisk; 2010.

10. Krueger R, Casey M. Focus groups: a practical guide for applied research. Thousand Oaks: Sage; 2014. 